\title{
Small-scale nutrient patchiness: Some consequences and a new encounter mechanism ${ }^{1}$
}

\section{Donald Scavia and Gary L. Fahnenstiel}

Great Lakes Environmental Research Laboratory, National Oceanic and Atmospheric Administration, 2300 Washtenaw Ave., Ann Arbor, Michigan 48104

\author{
Judith A. Davis \\ Division of Biological Sciences, University of Michigan, Ann Arbor 48109
}

Russell G. Kreis, Jr.

Great Lakes Research Division, University of Michigan

\begin{abstract}
Semicontinuous cultures of Lake Michigan algal assemblages were run at $0.15 \cdot$ day $^{-1}$ dilution rates under $P$ limitation for 41 days. In control cultures, nutrients were supplied to the entire culture once per day. In patch cultures, $10 \%$ of the cultures received a high concentration $10-\mathrm{min}$ pulse each day. Patch and control cultures received equal nutrient flux and achieved equal biomass levels; however, their species composition was different. Patch cultures were dominated by the filamentous blue-green alga Schizothrix calcicola and control cultures were dominated equally by S. calcicola, Nitzschia acicularis, and a group of phytoflagellates. These results, as well as shifts in subdominants, demonstrate the effect of small-scale, short term nutrient patches on species composition. Similar patch and control unialgal cultures revealed lower cell nutrient quotas for patchy cultures.

Microvideographic observations of Daphnia magna suspended in three concentrations of Chlamydomonas sp. allowed quantification of rates at which algal cells were collected, swept close by, and released via bolus rejection or outwashing of unpacked cells. Outwashing release rates of presumably unharmed cells increased from 31 to $71 \%$ of the collection rate as food concentration increased. It appears that algal outwashing is a significant mechanism for eliminating excess food. An important implication is the potential algal nutritional consequence of this very close nondestructive encounter.
\end{abstract}

In fresh and marine waters when nutrients are scarce and where zooplankton supply most of the $\mathrm{N}$ and $\mathrm{P}$, supply is likely to be heterogeneous (Lehman and Scavia $1982 a, b)$. If competition for those scarce resources occurs within patches of relatively high concentration rather than in uniformly low concentrations, then the "rules" of resource-based competition may be different than described previously (e.g. Tilman 1980). While the existence of such patches and their potential relevance to ecosystem dynamics can be debated on theoretical grounds, empirical information must be brought to bear on the issue. Small-scale nutrient patchiness and its effects on community structure are difficult to measure in nature; however, careful laboratory experiments can provide insight into potential

\footnotetext{
${ }^{1}$ GLERL Contribution 388
}

consequences. Nutrient temporal patchiness, explored through a series of comparisons between "pulse-and-chase" and continuous-nutrient-supply continuous cultures (e.g. Turpin and Harrison 1979, 1980), resulted in phytoplankton assemblages that differ from those given temporally uniform supplies. To explore the ecological significance of zooplankton-produced or other spatially discrete, nutrient patchiness, an experiment should provide spatial and temporal nutrient heterogeneity. This is because only a portion of a community will experience elevated nutrient concentrations.

We maintained natural algal assemblages in semicontinuous cultures with nutrientaugmented, filtered lake water supplied either uniformly or in discrete patches to explore the influence of small-scale nutrient patchiness on Lake Michigan species composition. We also ran patch and control semicontinuous unialgal cultures at equal 
dilution rates and nutrient supply rates to examine the effects of supply regime on nutrient cell quotas. We report here results from both studies.

Because encounter frequencies calculated from characteristics of theoretical nutrient plumes may be insufficient to balance algal nutrient requirements, we also made direct observations of algal flow fields surrounding Daphnia magna and describe an additional mechanism for nutrient enhancement through very close, nondestructive encounters.

We thank S. L. Fortner, L. A. Strong, and B. L. Wharram for technical assistance and J. R. Liebig and H. A. Vanderploeg for particle analysis. J. T. Lehman, S. S. Kilham, W. S. Gardner, K. G. Porter, and two anonymous reviewers provided comments on portions of the manuscript. We also thank J. R. Strickler for suggesting the video-taping study and assisting in design of the observation and video-taping systems and $\mathrm{J}$. T. Lehman for discussions and use of his microscope.

\section{Materials and methods}

Semicontinuous cultures $(750 \mathrm{ml})$ were maintained in clear 1 -liter polycarbonate flasks at $15^{\circ} \mathrm{C}$ under a $53 \mu$ Einst $\cdot \mathrm{m}^{-2} \cdot \mathrm{s}^{-1}$ 14:10 light/dark cycle for 41 days. The winter assemblage used in this study is similar to that of Lake Michigan's subsurface chlorophyll layer. We have grown these populations in semicontinuous culture under a range of nutrient additions and light regimes (Fahnenstiel et al. in press). Results from those studies clearly demonstrate a steady state biomass response to nutrients alone at $50 \mu$ Einst $\cdot \mathrm{m}^{-2} \cdot \mathrm{s}^{-1}$, an intensity at which the populations were light saturated.

Each day ( $4.5 \mathrm{~h}$ into the light cycle), 112.5 $\mathrm{ml}$ of each culture were poured off and an additional $75 \mathrm{ml}$ dispensed into $125-\mathrm{ml}$ sterile, clear polycarbonate flasks. For controls, after $10 \mathrm{~min}$ the $75 \mathrm{ml}$ were returned to the culture, followed by $112 \mathrm{ml}$ of $0.2-$ $\mu \mathrm{m}$ filtered Lake Michigan water plus 0.5 $\mathrm{ml}$ of artificial medium. For patch cultures, $0.5 \mathrm{ml}$ of artificial medium were added to the $75-\mathrm{ml}$ subsample and, after $10 \mathrm{~min}$, the contents were returned to the culture, followed by $112 \mathrm{ml}$ of filtered lake water. All transfers were made under sterile condi- tions. Culture dilution rates were $0.15 \cdot \mathrm{day}^{-1}$ $\left[\mu=\ln (1 / 1-d)=0.16 \cdot \mathrm{d}^{-1}\right]$. Artificial medium was composed of $26.4 \mu \mathrm{M} \mathrm{K}_{2} \mathrm{HPO}_{4}$, $825 \mu \mathrm{M} \mathrm{Na} \mathrm{SiO}_{3}, 1,650 \mu \mathrm{M} \mathrm{NaNO}$, and $0.528 \mathrm{ml} \cdot$ liter $^{-1}$ of trace metal and vitamin stock solution as defined in WC medium (Guillard and Lorenzen 1972).

Semicontinuous cultures are temporally patchy. In our controls, $P$ was raised by ca. $0.027 \mu \mathrm{M}$ at dilution time; however, in patch cultures, the $10-\mathrm{min}$ patch received a 0.18 $\mu \mathrm{M}$ increase. Thus, our experiments test the effect of the short duration, high concentration patch compared to the one-order-ofmagnitude-lower concentration patch experienced by the entire community.

Algal inocula and water for medium in the natural assemblage experiments were taken from 25-m depth in Lake Michigan $\left(43^{\circ} 00^{\prime} \mathrm{N}, 86^{\circ} 40^{\prime} \mathrm{W}\right)$ on 15 December 1982. Water depth at the station was $100 \mathrm{~m}$ and the temperature was $5.6^{\circ} \mathrm{C}$ at the surface and uniform at $5.2^{\circ}$ below $20 \mathrm{~m}$. Typical nutrient concentrations for this location and time of year are $0.06 \mu \mathrm{M}$ SRP, $0.10 \mu \mathrm{M}$ TDP, $18.5 \mu \mathrm{M}$ reactive $\mathrm{Si}, 21.3 \mu \mathrm{M} \mathrm{NO}_{3}{ }^{-}$, and $0.31 \mu \mathrm{M} \mathrm{NH}_{3}$ (Eadie et al. 1977; Rockwell et al. 1980). Molar ratios of nutrient supply (Si:P $=155, \mathrm{~N}: \mathrm{P}=152$ from lake water plus medium) were indicative of $P$ limitation (Rhee and Gotham 1980; Tilman and Kilham 1976; Tilman 1981).

Preserved phytoplankton slides were prepared (Dozier and Richerson 1975) at about 4-day intervals. Particle size spectra and total particle volume of preserved samples were analyzed (Coulter Counter model TA II 50- and 200- $\mu \mathrm{m}$ aperture tubes: Vanderploeg 1981) for days 1,18 , and 41 of the experiment.

Procedures for unialgal cultures were as above, with the following exceptions. Replacement medium was WC without P. Separate additions of $\mathrm{P}$ raised patch concentrations to $12 \mu \mathrm{M}$ for Ankistrodesmus falcatus and $2.5 \mu \mathrm{M}$ for Asterionella formosa. These values are 1 order of magnitude higher than their respective control pulses and are about three times their respective $K_{s}$ values for $\mathbf{P}$ uptake. Patch size was $10 \%$ of culture volume and patch duration was $5 \mathrm{~min}$ for $\mathrm{An}$ kistrodesmus and 10 min for Asterionella. Light and temperature were $110 \mu$ Einst. $\mathrm{m}^{-2} \cdot \mathrm{s}^{-1}(14: 10, \mathrm{~L}: \mathrm{D})$ and $20^{\circ} \mathrm{C}$. Cultures 
were run until dark-adapted in vivo fluorescence (Turner Designs fluorometer) and cell counts (Sedgwick-Rafter) reached steady state.

For direct observation of algal flow fields around Daphnia, a video camera was placed behind the camera port (a $1.6 \times$ projection lens) of an Olympus IMT inverted microscope. The microscope, lying horizontally, was fitted with a platform mounted to its stage to hold a $3.8-\times 12.5-\times 12.5-\mathrm{cm}$ aquarium. A 32-mm, $4 \times$ Bausch \& Lomb objective provided the long working distance required to manipulate animals. Illumination was dark-field, obtained by inserting a phase-contrast annulus in the light path of an Olympus ultralong working distance condenser.

Four-six individuals of $D$. magna (2.0 $3.0 \mathrm{~mm}$ ) were placed in $300-\mathrm{ml}$ reagent bottles containing suspensions of Chlamydomonas sp. $\left(1.48 \times 10^{3} \mu \mathrm{m}^{3} \cdot\right.$ cell $^{-1}, 2.32 \times$ $10^{-7} \mu \mathrm{g} \mathrm{C} \cdot \mu \mathrm{m}^{-3}$ : H. A. Vanderploeg unpubl.) adjusted to cell densities of 700 , 5,000 , or 17,000 cells $\cdot \mathrm{ml}^{-1}(0.24,1.72$, or $5.84 \mathrm{mg} \mathrm{C} \cdot$ liter $^{-1}$ ). Reagent bottles were placed in an incubator at low light $(0.8$ $\mu$ Einst $\cdot \mathrm{m}^{-2} \cdot \mathrm{s}^{-1}$ ) and $20^{\circ} \mathrm{C}$ on a rotating wheel $(0.5 \mathrm{rpm})$, and cell densities were adjusted to original levels each day for 3-4 days before experiments.

For feeding observations, a dog hair was attached with a cyanoacrylic glue on one end to the dorsal side of the carapace near the head of the Daphnia and on the other end to a glass microscope slide. Several animals were attached in this way to a single slide and the entire group was suspended in the aquarium filled with suspensions of Chlamydomonas at the desired cell concentration. Taping sequences were carried out between 10 and $110 \mathrm{~min}$ after the animals were placed in the aquarium. Tapes were analyzed by displaying 8-25-s sequences on a television screen and tracing algal trajectories onto a transparent overlay. We also analyzed longer sequences $(0.5-1.0 \mathrm{~min})$ to determine rates of "rejection" by the postabdominal claw.

\section{Results and discussion .}

In the natural assemblage experiments, initial phytoplankton consisted of ca. $80 \%$ phytoflagellates and $15 \%$ centric diatoms and were typical of Lake Michigan winter conditions. Total cell counts were $1.18 \times$ $10^{3} \mathrm{cells} \cdot \mathrm{ml}^{-1}$ and total particle volume was $0.915 \times 10^{6} \mu \mathrm{m}^{3} \cdot \mathrm{ml}^{-1}$. After 41 days, cell densities averaged 2.94 and $6.18 \times 10^{4}$ cells $\cdot \mathrm{ml}^{-1}$ for the two control and two patch cultures. Total particle volume reached 2.41 and $2.56 \times 10^{6} \mu \mathrm{m}^{3} \cdot \mathrm{ml}^{-1}$. This average $2.7-$ fold increase in response to the augmented nutrient supply, in combination with previous nutrient-light experiments (Fahnenstiel et al. in press), further illustrates that our cultures were nutrient limited.

Patch and control cultures achieved similar biovolume levels (consistent with equal nutrient supply and dilution rates); the differences in total cell densities were due to differences in final species composition.

In the two control cultures, 72 and $83 \%$ of the cells were approximately equally distributed among Nitzschia acicularis (Kutz.) Wm. Sm. (24, 25\%), Schizothrix calcicola (Ag.) Gom. (40, 24\%), and a group of small phytoflagellates (predominantly chrysophytes $<10 \mu \mathrm{m} ; 19,23 \%)$. Patch cultures were clearly dominated by $S$. calcicola $(85$, $88 \%$ ), with $N$. acicularis $(4.3,5.4 \%)$ and the flagellates $(8.5,3.5 \%)$ less abundant. Trends in abundance for days 31-41 (Fig. 1) show consistency between replicates and differences between patch and control. The diatom $N$. acicularis and the flagellates were slightly more abundant in the controls; however, the filamentous blue-green $S$. calcicola in patch cultures reached almost six times the densities of the controls. Its small cell size $(0.8-\mu \mathrm{m}$ diam, $6.0 \mu \mathrm{m}$ long) and higher abundance are consistent with its replacement of the much larger Nitzschia (3- $\mu \mathrm{m}$ diam, $45 \mu \mathrm{m}$ long).

Schizothrix calcicola is commonly found in Lakes Michigan and Huron (Stoermer and Kreis 1980; Stoermer and Tuchman 1979; Stoermer and Stevenson 1979). The cause of its rise to importance in all our cultures is unclear; however, samples taken in May and June of the following spring (1983) from the same location as our inocula contained up to $20-30 \% \mathrm{~S}$. calcicola by numbers.

Differences between patch and control cultures were also seen for two less abundant species. Ochromonas sp. comprised an average $5.0 \%$ of the control cultures, yet only 

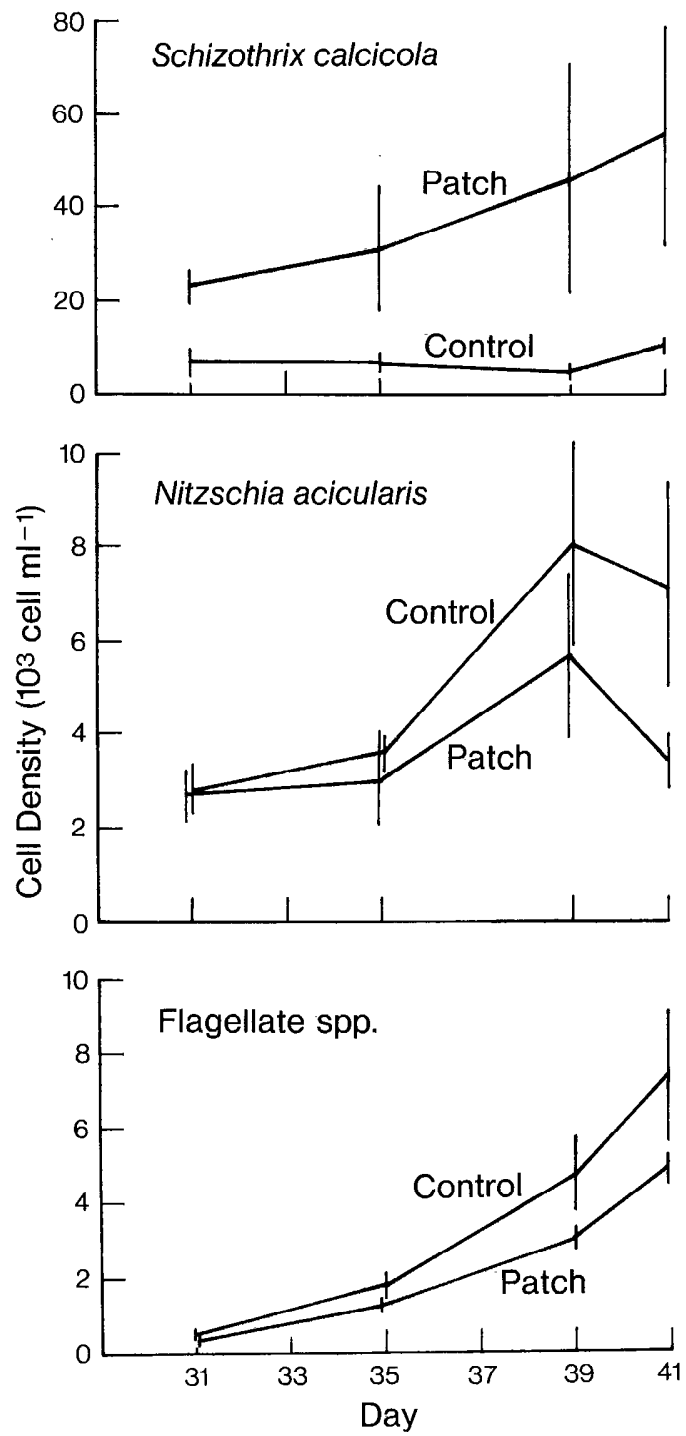

Fig. 1. Cell densities vs. day of competition experiment in semicontinuous cultures. Ends of bars represented values from replicate cultures. Midpoints are connected. Characteristics of patch and control cultures are given in text.

$0.55 \%$ of the patch cultures. Rhizosolenia eriensis (H. L. Sm.) comprised 5.7 and $0.16 \%$ of the control and patch cultures.

All of our cultures received equal treatment (light, temperature, nutrient flux, dilution rate, handling, assemblage inocula), with the only difference between patch and control being the manner in which nutrients
Table 1. Cell P quotas for patch and control unialgal culturcs.

\begin{tabular}{lcc}
\hline \multicolumn{2}{c}{$\mu\left(\mathrm{d}^{-1}\right)$} & $q\left(10^{-9} \mu \mathrm{mol} \cdot \mathrm{ccll}^{-1}\right)$ \\
\hline Ankistrodesmus falcatus & \\
Patch & 0.22 & 1.83 \\
Patch & 0.22 & 1.99 \\
Control & 0.22 & 2.40 \\
Asterionella formosa & & \\
Patch & 0.3 & 9.29 \\
Patch & 0.3 & 8.45 \\
Control & 0.3 & 19.46 \\
Control & 0.3 & 10.37 \\
Patch & 0.25 & 10.01 \\
Control & 0.25 & 11.85 \\
\hline
\end{tabular}

were added. Although it is clear that algal community production is controlled by the rate at which the limiting nutrient is supplied to the water, the impact of the mode of that supply may affect the arrangement of species within the community (Tilman 1980; Lehman and Scavia 1982b; Lehman 1982). Our results show natural communities to be influenced by a heterogeneous nutrient supply even when only a small portion of the community is exposed to nutrient patches for relatively short periods. The generality of this effect, and the mechanisms controlling it, need further attention; however, the potential for nutrient patchiness affecting species composition is clear. Our experiments were all run at growth rates indicative of Lake Michigan plankton (Fahnenstiel and Scavia unpubl.) because the existence and use of nutrient patches does not infer rapid growth rates. In fact patchiness could lead to slower growth (Lehman 1982).

Our unialgal experiments provide some insight into a possible mechanism underlying competition in a heterogeneous environment. In patch and control semicontinuous cultures at the same dilution rate and nutrient supply rate, patch cultures invariably produced populations with lower nutrient quotas (Table 1). This suggests that cell quotas are distributed within the population in such a way as to maintain a growth rate comparable to that of a uniform population, yet the population has, on average, less nutrient per cell. This implies a more efficient use of the limiting resource in the 
patchy environment. If the plasticity of capitalizing on nutrient hetcrogeneity does not exist in all species, or is at least variable among species, then competitive displacement within homogeneous and heterogeneous environments might be different.

In all of our experiments, a relatively small portion of the population or assemblage (10\%) was exposed to short (0.0035-0.0069 days) pulses of high nutricnt concentration once a day. Though patch contact time represents only $0.035-0.069 \%$ of total potential contact (i.e. entire population all day), it is provided as a single $5-10$-min pulse rather than as repeated pulses of much shorter duration. The latter are more likely to occur if zooplankton-produced patches are responsible for the heterogencity. Shorter, rcpeated pulses may in fact be more advantageous because feedback control from internal nutrient pools would reduce uptake rates during the longer patch experiences. However, whether an equivalent of $10 \%$ of the population encounters patches for a total of $5-10$ min per day in nature is still speculative.

The role of encounters between herbivorous zooplankton and algae as a mechanism of algal nutrient enrichment (McCarthy and Goldman 1979; Goldman et al. 1979) has been shown empirically for cells passing unharmed through zooplankton guts (Lefevre 1942; Porter 1976) and for cells encountering concentrated nutrients released by swimming zooplankton (Lehman and Scavia 1982a,b). The importance of enrichment via encounters with these millimeter-scale patches has been disputed theoretically (Jackson 1980; Williams and Muir 1981; Currie 1984), on the basis primarily of calculations of plume characteristics and expected encounter frequencies. Encounter frequencies can be calculated from the crosssectional area of the plume (defined by some critical concentration contour), swimming speed of the animal, and animal population density. If the algal population is uniform and stationary, frequencies can be derived directly from the volume of water traversed by the animals (e.g. Currie 1984). While Lehman and Scavia (1982b) demonstrated that this nutrient plume encounter is possible, they also stated explicitly (p. 5004)

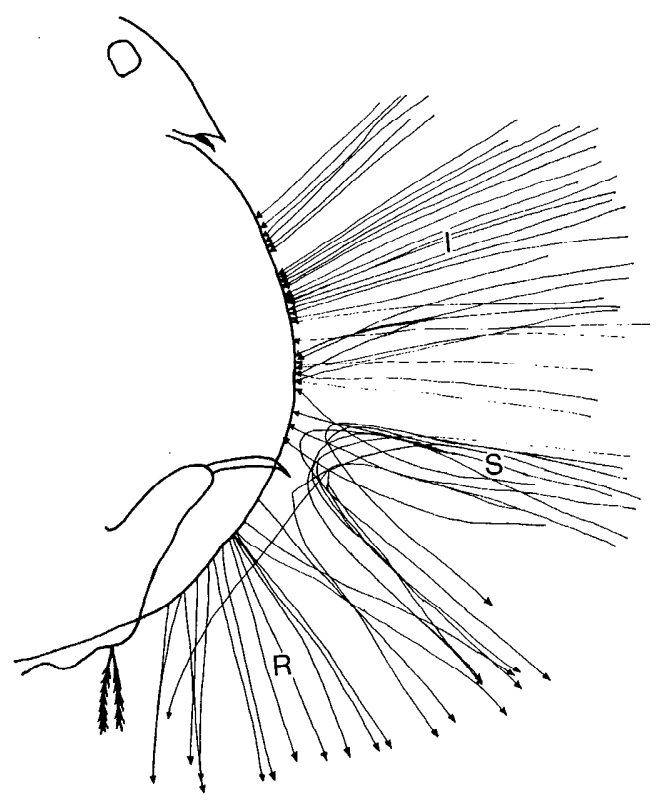

Fig. 2. Outline of a Daphnia magna showing 10-s trajectories of Chlamydomonas cells brought through carapace gape (I), released from carapace (R), and swept close by $(\mathrm{S})$. Outline and trajectories were traced from video tapes displayed on a television screen.

that it is not an exhaustive description of encounter possibilities. Strickler (1982) showed clearly that trajectories of algal cells caught in feeding currents resulted in actual encounter volumes much greater than would be calculated from swimming speeds alone. What portion of the cells influenced by feeding currents survive the event and perhaps gain nutrients? We report here results of direct observation of $D$. magna feeding in suspensions of Chlamydomonas sp. that show that it can be a significant portion and suggest that encounter frequencies may in fact be much higher than would be calculated by the simpler models.

We recorded on video tape the tracks of algal cells drawn into the carapace of a Daphnia in a region midway between rostrum and postabdomen (I), of cells streaming posteriorly out of the carapace ventral to the postabdomen (R), and of cells drawn near but not through the carapace gape (S) (Fig. 2). These trajectories were traced for periods without swimming motions of the antennae. During such motions, a free- 
swimming animal will move relative to the water and particles. This will add a posteriorly directed component to the trajectories. It should not affect the balance of cells entering and leaving the carapace gape.

With our video system we were unable to determine the mechanism by which released cells were processed. They were released, however, as singular cells moving in a steady stream considerably faster than those entering the carapace or those swept by. J. R. Strickler first observed this release with high-resolution cinematography and associated it with adjustments in appendage-mediated hydraulics. Cells of Euglena collected near Daphnia's mouthparts were flushed postabdominally ventral to the gut, out of the carapace, and swam away apparently unharmed. In our study, released cells were not egested from the anus nor removed by the often described bolus rejection by the postabdominal claw. Packed boli rejected by the claw are quite distinct and secondary to the mechanism we report. These rejections appear to be used most often to clear appendages of entanglements and their costs may relate more to increased energy spent than to loss of food consumed (Porter et al. 1982; Porter and McDonough 1984).

If we treat each taped sequence as a snapshot of steady state processes, a mass balance can be calculated and gross ingestion (I) can be compared to net ingestion (I $\mathrm{R})$; the latter is the quantity typically measured in feeding experiments. Porter et al. (1982) reported net ingestion rates (radiotracer technique) for similar-sized $D$. mag$n a$ at $20^{\circ} \mathrm{C}$ in varying food concentrations. Their figure 1 is redrawn here, based on their carbon estimates for the alga Chlamydomonas reinhardi $\left(2.0 \times 10^{-5} \mu \mathrm{g} \mathrm{C}\right.$. cell ${ }^{-1}$ ), with our estimates of gross and net carbon ingestion rates added (Fig. 3). Our data are consistent with their observations of continued filtering-appendage movements above the incipient limiting concentration which led to gross ingestion rates (our data) increasing with increasing food concentration. They attributed saturation of net ingestion rates to increased bolus rejection above the incipient limiting concentration. Our results show that "outwashing" release of apparently unharmed cells is an

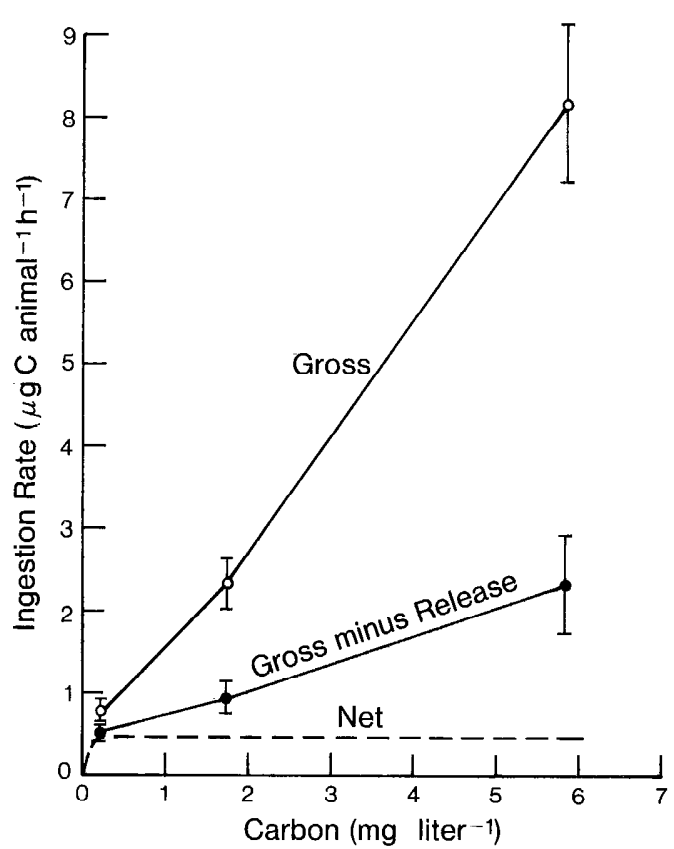

Fig. 3. Gross and net ingestion rates vs. food concentration. Gross ingestion $(O$, mean $\pm S E$ ) calculated from cells brought into carapace. Net ingestion calculated as difference between rates of cell movement into and out of carapace $(\Theta$, mean $\pm S E)$, and modified from Porter et al. (1982) (broken line).

additional and perhaps more significant mechanism for removing excess collected food. Although our observations of "rejection" movements as a function of food concentration are consistent with those of Porter and Orcutt (1980) and Porter et al. (1982) (Fig. 4a), none of the movements at 0.24 $\mathrm{mg} \mathrm{C} \cdot \operatorname{liter}^{-1}$ and only 4.8 and $4.5 \%$ of the movements at 1.72 and $5.84 \mathrm{mg} \mathrm{C} \cdot$ liter $^{-1}$ actually led to packed-bolus rejection. We could not include bolus rejection in our mass balance because we could not determine bolus volumes, and their compaction precluded accurate estimate of mass loss. However, the difference between our net ingestion rates and those reported previously may be attributed to bolus rejection.

We also observed clouds of individual cells released after $35 \%$ of the postabdomen flexes at the highest food concentration $\left(1.7 \times 10^{-4}\right.$ cells $\left.\cdot \mathrm{ml}^{-1}\right)$. These cells were not packed and were swept clear of the animal by other feeding currents. The clouds con- 

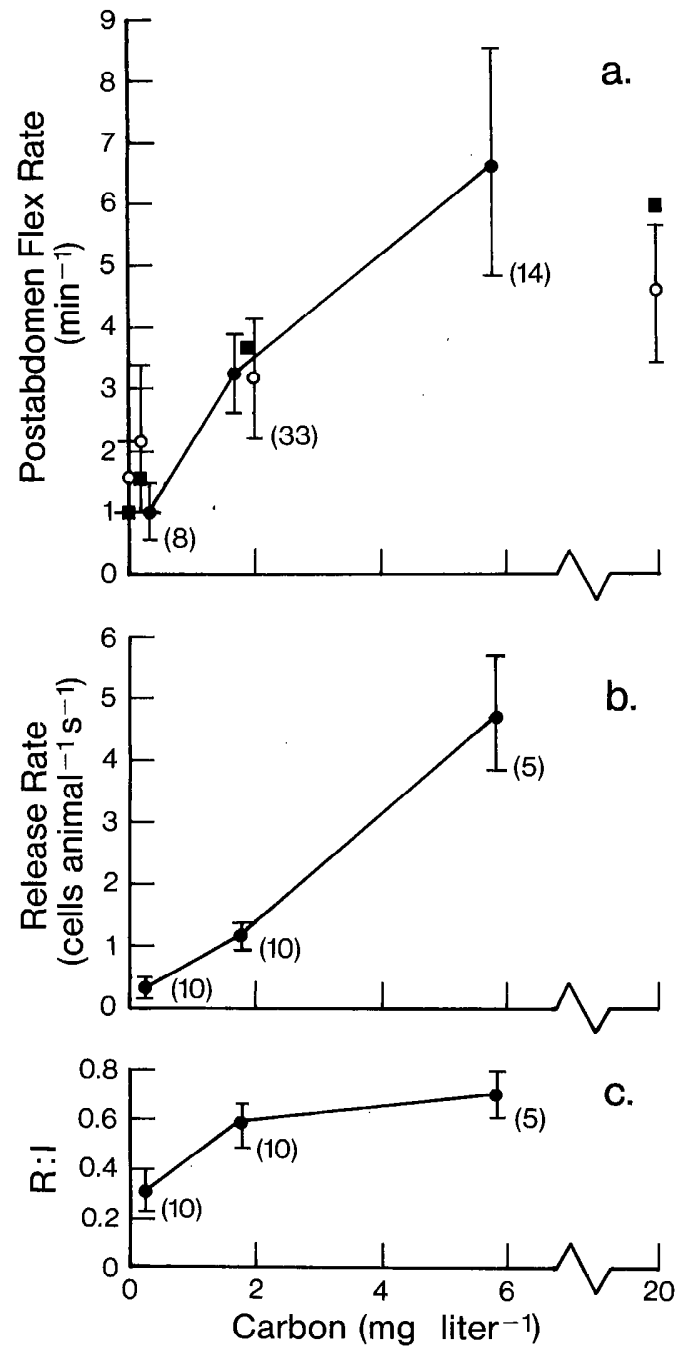

Fig. 4. a-"Rejection" rate of postabdominal claw; $\mathrm{b}$ - "outwash" release rates; and c-ratio of release (R) to gross ingestion (I) vs. food concentration. - Our data, mean \pm SE; O-redrawn mean and $95 \%$ C.I. from Porter et al. (1982); E-mean values from Porter and Orcutt (1980). Numbers in parentheses are sample sizes from our experiments.

tained, on average, $60(\mathrm{SE}=11.1)$ cells. These releases were obviously more common than packed boli at the high concentration; however, none was observed at the lower concentrations.

We now turn to the role of this "outwashing" release as a vehicle of nutrient enrichment for algal cells. As discussed above, these cells do not experience the compactive force of the postabdominal claw during its rejection motion. They remain unpacked and, in more motile cells (see above), observably viable. The release rate of these individual cells rose dramatically from $0.25(\mathrm{SE}=0.078)$ to $4.74(0.88)$ cells . animal ${ }^{-1} \cdot \mathbf{s}^{-1}$ with increasing cell abundance (Fig. $4 \mathrm{~b}$ ). Thus $31-71 \%$ of the cells brought through the carapace gape were released presumably unharmed (Fig. 4c).

More work needs to be done to determine if the percentage continues to decrease with lower food concentrations. One could argue that results from these relatively high food

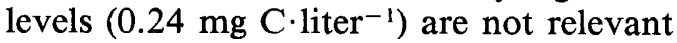
to nutrient acquisition via microscale encounters because higher particulate carbon concentrations are typical of more eutrophic environments. This, of course, is not true since the concentrations of limiting nutrients typically are extremely low in the epilimnion of stratified, eutrophic lakes, both small and large (e.g. Lake 227, 4-6 mg $\mathrm{C} \cdot$ liter $^{-1},<1.0 \mu \mathrm{g} \cdot$ liter $^{-1}$ SRP: Schindler et al. 1973; Lake Erie, $0.36 \mathrm{mg} C \cdot$ liter $^{-1}$, 0.9 $\mu \mathrm{g} \cdot$ liter $^{-1}$ SRP: Burns and Ross 1972). Also, concentrations of particulate organic carbon in the range of $0.1-0.3 \mathrm{mg} \mathrm{C} \cdot$ liter $^{-1}$ are not restricted to eutrophic waters, but are in fact common in lakes (Wetzel 1983) and coastal oceans (Parsons 1975).

Most characterizations of zooplanktongenerated nutrient plumes consider excretion as a point source. Pennak (1978) and Meglisch (1972) describe glands and tubule ports that are excretory in nature; however, it is also likely that nutrient exchange takes place across the crustacean body wall (suggested by the need for osmoregulatory mechanisms). Scavia and McFarland (1982), for examplc, reported dramatic increases in $P$ release associated with increased exposure of the soft body wall during molts in $D$. magna. Either exchange across the body wall or release from the maxillary or shell glands near the anterior end of the valves will concentrate nutrient outside the soft body but within or around the carapace. These regions may provide sites of nutrient enrichment for a significant portion of the algal cells that are entrained but released, rather than passed to the foregut. Cells swept close 
to the carapace (Fig. 2) but not collected may also enter these nutrient-rich regions.

These observations of nondestructive encounters with zooplankton feeding appendages are not unique to $D$. magna. We have made similar observations with Daphnia pulex and Price et al. (1983) report singlecell rejections (without actual maxilliped contact) by the marine copepod Paracalanus parvus feeding on Thalassiosira weissflogii. Similar collection and rejection of large individual cells from a mixture of Chlamydomonas species by the freshwater copepod Diaptomus sicilis are common, especially at high food concentrations (H. A. Vanderploeg and G. A. Paffenhöfer pers. comm.). The relationship between the frequency of occurrence of these encounters and environmental conditions (e.g. food concentration) awaits further study, but our results demonstrate yet another dimension to the complex interactions between algae and zooplankton.

\section{References}

Burns, N. M., AND C. Ross. 1972. Oxygen-nutrient relationships within the central basin of Lake Erie, p. 171-192. In H. E. Allen and J. R. Kramer [eds.], Nutrients in natural waters. Wiley.

Currie, D. J. 1984. Microscale nutrient patches: Do they matter to the phytoplankton? Limnol. Oceanogr. 29: $211-214$.

Dozier, B. J., AND P. J. Richerson. 1975. An improved membrane filter method for the enumeration of phytoplankton. Int. Ver. Theor. Angew. Limnol. Verh. 19: 1524-1529.

Eadie, B. J., R. L. Chambers, J. M. MalczyK, AND A. L. LANGSTON. 1977. The effect of the Grand River runoff on Lake Michigan. Int. Jt. Comm. PLUARG Rep. Windsor, Ontario. 82 p.

Fahnenstiel, G. L., D. Scavia, and C. L. Schelske. In press. Nutrient-light interactions in the Lake Michigan subsurface chlorophyll layer. Int. Ver. Theor. Angew. Limnol. Verh. 22.

Goldman, J. C., J. J. McCarthy, and D. G. Peavey. 1979. Growth rate influence on the chemical composition of phytoplankton in oceanic waters. Nature 279: 210-215.

Guillard, R. R., AND C. J. LoREnZen. 1972. Yellowgreen algae with chlorophyllide $c$. J. Phycol. 8: 1014.

JACkson, G. A. 1980. Phytoplankton growth and zooplankton grazing in oligotrophic oceans. $\mathrm{Na}-$ ture 284: 439-441.

LEFEVRE, M. 1942. L'utilization des algues d'eau douce par des cladoceres. Bull. Biol. Fr. Belg. 76: 250276.

Lehman, J. T. 1982. Nutritional significance of nu- trient patches to the phytoplankton: Productivity and species composition, p. 210-229. In Fish ecology 3. Univ. Miami Tech. Rep. 82008.

- AND D. SCAVIA. 1982a. Microscale patchiness of nutrients in plankton communities. Science 216: 729-730.

—. AND —. 1982b. Microscale nutrient patches produced by zooplankton. Proc. Natl. Acad. Sci. 79: 5001-5005.

McCarthy, J. J., and J. C. Goldman. 1979. Nitrogenous nutrition of marine phytoplankton in nutrient-depleted waters. Science 203: 670-672.

MEGLisCH, D. A. 1972. Invertebrate zoology, 2nd ed. Oxford.

Parsons, T. R. 1975. Particulate organic carbon in the sea, p. 365-385. In J. P. Riley and G. Skirrow [eds.], Chemical oceanography, v. 2. Academic.

PENNAK, R. W. 1978. Freshwater invertebrates of the United States. Wiley.

Porter, K. G. 1976. Enhancement of algal growth and productivity by grazing zooplankton. Science 192: $1332-1334$.

- J. Gerritsen, AND J. D. ORcutt, JR. 1982. The effect of food concentration on swimming patterns, feeding behavior, ingestion, assimilation, and respiration by Daphnia. Limnol. Oceanogr. 27: 935-949.

- ANI R. MCDonough. 1984. The energetic cost of response to blue-green algal filaments by cladocerans. Limnol. Oceanogr. 29: 365-369.

- AND J. D. ORCUTT, JR. 1980. Nutritional adequacy, manageability, and toxicity as factors that determine the food quality of green and bluegreen algae for Daphnia. Am. Soc. Limnol. Oceanogr. Spec. Symp. 3: 268-281. New England.

Price, H. J., G. A. PAFFENHÖFER, AND J. R. STRICKLER. 1983. Modes of cell capture in calanoid copepods. Limnol. Oceanogr. 28: 116-123.

Rhee, G. Y., AND I. J. Gotham. 1980. Optimum $\mathrm{N}: \mathrm{P}$ ratios and coexistence of planktonic algae. $\mathrm{J}$. Phycol. 16: 486-489.

Rockwell, D. C., D. S. DeVault III, M. F. Palmer, C. V. MARION, AND R. J. BOWDEN. 1980. Lake Michigan intensive survey 1976-1977. U.S. EPA Rep. EPA-905/4-80-003-A. Chicago.

SCAvia, D., AND M. J. MCFARLAND. 1982. Phosphorus release patterns and the effects of reproductive stage and ecdysis in Daphnia magna. Can. J. Fish. Aquat. Sci. 39: 1310-1314.

SCHINDleR, D. W., AND OTHERS. 1973. Eutrophication of Lake 227 by addition of phosphate and nitrate. The second, third, and fourth years of enrichment, 1970, 1971, 1972. J. Fish. Res. Bd. Can. 30: $1415-1440$.

Stoermer, E. F., And. R. G. Kreis, Jr. 1980. Phytoplankton composition and abundance in southern Lake Huron. U.S. EPA Rep. EPA-600/3-8061. Duluth.

- And R. J. Stevenson. 1979. Green Bay phytoplankton composition, abundance, and distribution. U.S. EPA Rep. EPA-105/3-79-002. Chicago.

$\longrightarrow$, AND M. L. TuChMAN. 1979. Phytoplankton assemblages of the nearshore zone of southern Lake 
Michigan. U.S. EPA Rep. EPA-905/3-79-001. Chicago.

STRICKLER, J. R. 1982. Calanoid copepods, feeding currents, and the role of gravity. Science 218: 158160.

TilmaN, D. 1980. Resources: A graphical-mechanistic approach to competition and predation. Am. Nat. 116: 362-393.

1981. Tests of resource competition theory using four species of Lake Michigan algae. Ecology 62: 802-815.

, AND S. Kilham. 1976. Phosphate and silicate growth and uptake kinetics of the diatoms Asterionella formosa and Cyclotella meneghiniana in batch and semicontinuous culture. J. Phycol. 12: 375-383.

TurPin, D. H., AND P. J. Harrison. 1979. Limiting nutrient patchiness and its role in phytoplankton ecology. J. Exp. Mar. Biol. Ecol. 39: 151-166.

. 1980. Cell size manipulation in natural marine, planktonic, diatom communities. Can. J. Fish. Aquat. Sci. 37: 1193-1195.

VANDERPLOEG, H. A. 1981. Effect of the algae length/ aperture tube length ratio on Coulter analyses of lake seston. Can. J. Fish. Aquat. Sci. 38: 912-916.

WeTZEL, R. G. 1983 . Limnology. Saunders.

Williams, P. J., AND I. R. Muir. 1981. Diffusion as a constraint on the biological importance of microzoncs in the sea, p. 209-218. In J. C. Nihoul [ed.], Ecohydrodynamics. Elsevier Ocean. Sci. Ser. v. 32 .

Submitted: 3 May 1983 Accepted: 30 January 1984 